\title{
Intraglandular Route of Administration
}

National Cancer Institute

\section{Source}

National Cancer Institute. Intraglandular Route of Administration. NCI Thesaurus. Code C149602.

Administration of a medicinal product directly into a gland, usually by injection. 